\title{
COMPARISON OF NATIONAL EXTENSION SYSTEMS: APPLICATION OF THE BEST-FIT FRAMEWORK
}

\section{Kristin Davis}

\subsection{Introduction}

As seen in Chapter 2, extension has evolved over the decades in various ways: in terms of its governance structure, in terms of who provides extension, in terms of capacity (staffing) and management, and in terms of advisory methods. However, the analysis in Chapter 2 was centered on the global level, focusing on the big picture and trends over time. This did not include more detailed assessments of national and regional extension systems using the best-fit characteristics. This chapter offers a synthesis of information from in-depth country and regional assessments that were conducted mainly since 2015. These assessments took place with various partners and projects. To pull out comparisons of the national systems, this chapter applies the best-fit approach (see Chapter 1). Note that this level of analysis still does not look at the performance or the impact of extension services (Chapters 4-8 cover performance assessment issues). Rather, this chapter presents a snapshot of extension services zooming in at the country or regional level.

The best-fit approach analyzes extension and advisory services from a systems perspective. It uses the four best-fit characteristics: governance structures, capacity, management, and advisory methods used. The "governance structures" refer to the institutional setup of extension services (often based on national policies). They include the role of the public sector in extension services, the level of privatization, the degree of decentralization, the funding mechanisms, and the coordination and linkages. "Capacities" refer to the human and organizational competencies, motivation, and financial and physical assets. "Management style" is the way in which extension is managed within the respective governance structures. This also includes training and retraining efforts for extension staff at various levels; organizational management procedures carried out; incentives and methods of performance assessment of individual agents; and monitoring and evaluation of the services. "Advisory methods" are the means used by field extension staff in interactions with farmers. "Methods" can be classified in various (and overlapping) ways, 
such as number of clientele involved (individuals, groups); types of decisions on which advice is provided (specific to the production of certain crops or livestock, managerial decisions, group activities, etc.); and media used (radio, television, Internet, print, video, group meeting, face-to-face visits, etc.).

The rest of the chapter is organized as follows. Section 3.2 looks at governance structures, including funding, pulling out findings of interest from various countries. Section 3.3 looks at capacity, including human resources and training across the set of countries, while section 3.4 looks at management issues. Section 3.5 covers advisory methods, and section 3.6 contains crosscutting issues. Section 3.7 concludes, and section 3.8 discusses some recommendations on potential indicators for extension and advisory services using the best-fit framework. Table 3.1 provides summary information by country, looking at similarities and differences according to elements of the best-fit framework. The table includes both qualitative and quantitative information. The text focuses on archetypical countries that typify certain elements of the four variables in the best-fit framework.

The source of information for these country and regional analyses is a number of in-depth reports, mainly out of extension projects described below or manuscripts prepared by individuals (for example, Cambodia-Ke and Babu 2018; Central Asia and the Caucasus-Dosov 2018; India-Babu and Shishodia 2018; Latin America-Preissing et al. 2018; Viet Nam-Ngan and Babu 2018; Zimbabwe-Mwakiwa 2017) as well as the five country cases described in Chapters 4-8 (Brazil [Chapter 4], Uganda [Chapter 5], Ethiopia [Chapter 6], Malawi [Chapter 7], and the Democratic Republic of the Congo [Chapter 8]). Secondary sources of information are used (except for the five country cases in Part 2, which use primary data). The reports were selected because they contain recent and in-depth analysis on agricultural extension and advisory services at the country or regional level. ${ }^{1}$ Furthermore, the sources used had to include relevant data about the best-fit characteristics. More information on methods used for each study is included in Table 1.1 in Chapter 1. Note that Part 2 also includes in-depth country case studies; however, these country cases are focused on performance of extension services rather than the broad snapshot according to the best-fit framework that is covered in this chapter. They do, however, still analyze performance using the best-fit framework.

1 The oldest reports are from 2011; however, these country cases also have data from 2017 and later. 


\subsection{Governance Structures}

As mentioned above, "governance structures" include the institutional setup and management of extension services and the roles of different types of providers, the degree of privatization and decentralization, the funding mechanisms, and the coordination and linkages.

\section{Policies and Strategies}

Policies and strategies determine governance structures, financing, and provision of extension services. Many countries have no policy at all, some have policies that are not well-implemented, and a few have strong policies that are well-implemented (see Table 3.1). Countries with no specific extension strategies include Azerbaijan, Kazakhstan, Mozambique, Viet Nam, and Zimbabwe. Such countries often root any strategies and activities in national agriculture policies. For instance, extension in Mozambique has been guided by a series of master plans and programs (Cuangara and Thompson 2018), although it is now developing a formal policy on extension.

Countries such as Ghana, Kenya, and Liberia have extension policies in place that are somewhat outdated and not implemented as well as they could be (in Kenya, due in part to the decentralization that occurred after policy development). Malawi (Chapter 7) is currently updating its policy. Postconflict countries such as the Democratic Republic of the Congo (Chapter 8) are considering a national extension policy as part of their recent agricultural development programs. A few countries stand out as having strong extension policies coupled with government and other types of support for implementation of these policies. These include Brazil (Chapter 4), Rwanda, and Ethiopia (Chapter 6).

\section{Providers}

The public sector is often the chief actor in extension provision in most of the countries examined. For example, the Brazilian System for Technical Assistance and Rural Extension mandated the Ministry for Agrarian Development as the official federal organ responsible for the smallholder sector to transfer funds to extension organizations in the country through their state and municipality counterparts. ${ }^{2}$ In Cambodia the Department of Extension was the central body responsible for extension within the General Directorate of Agriculture (Ke and Babu 2018). $\quad$ (text continues on page 66)

2 As of 2017, the Ministry for Agrarian Reforms has been dismantled and located within a Secretariat of the President's Office. 
TABLE 3.1 Summary of country extension status based on best-fit framework characteristics

\begin{tabular}{|c|c|c|}
\hline \multirow[b]{2}{*}{ Country or region } & \multicolumn{2}{|r|}{ Governance structure } \\
\hline & Providers and policies & Financing and budget \\
\hline $\begin{array}{l}\text { Central Asia and } \\
\text { Caucasus (Armenia, } \\
\text { Azerbaijan, Geor- } \\
\text { gia, Kazakhstan, } \\
\text { Kyrgyzstan, Tajikistan, } \\
\text { Uzbekistan) } \\
\text { (Dosov [2018]) }\end{array}$ & $\begin{array}{l}\text { Many nongovernmen- } \\
\text { tal; weak public and } \\
\text { private. } \\
\text { No policies; extension } \\
\text { usually falls under } \\
\text { broader agrarian } \\
\text { policies (for example, } \\
\text { in Azerbaijan and } \\
\text { Kazakhstan). }\end{array}$ & $\begin{array}{l}\text { Little government } \\
\text { funding; many donors } \\
\text { and nongovernmental } \\
\text { organizations (NGOs). }\end{array}$ \\
\hline $\begin{array}{l}\text { Latin America (Preiss- } \\
\text { ing et al. [2018]) }\end{array}$ & $\begin{array}{l}\text { Wide variety of } \\
\text { providers: government, } \\
\text { private, producer } \\
\text { organizations. } \\
\text { Policies related to } \\
\text { extension usually } \\
\text { part of broader sector } \\
\text { policies. }\end{array}$ & $\begin{array}{l}\text { Diverse including } \\
\text { national, departmen- } \\
\text { tal, and municipal } \\
\text { governments; producer } \\
\text { payments; local dona- } \\
\text { tions; development aid; } \\
\text { cofinancing schemes } \\
\text { in Peru, Chile, Nicara- } \\
\text { gua, and Colombia. }\end{array}$ \\
\hline
\end{tabular}

\author{
Moderate to strong \\ linkages in most cases; \\ Argentina and Brazil have \\ incentive systems and \\ mechanisms for exchange \\ with researchers; formal \\ links in El Salvador, \\ Guatemala, Honduras, and \\ Nicaragua.
} among public, donors, and NGOs.

Have difficulties due to pluralism and lack of mechanism to coordinate. funding goes to salaries and capital costs.

and Davis [2017];

Rahman et al. [2017]; Swanson [2011]) strong public provision and many nongovernmental providers.

Policy was updated in 2012.

Brazil (see Chapter 4)

Strong government role but in coordinating and financing many pluralistic players from private and nongovernmental sectors.

Extension policy enacted in law.

Burundi (Ludgate and Public mainly.

Federal—universal coverage attempted but not yet reached.

System of public calls for services to smallholders and state-level functionaries for large farms.

Public funding reduced

No information.

Plan National d'Investissement Agricole for 2012 to 2017. in 2005 due to reforms aimed to boost the private sector. 


\begin{tabular}{|c|c|c|c|}
\hline \multirow[b]{2}{*}{ Capacity (staffing) } & \multirow{2}{*}{$\begin{array}{l}\text { Management style (including } \\
\text { monitoring and evaluation, } \\
\text { incentives, training) }\end{array}$} & \multicolumn{2}{|c|}{ Advisory methods } \\
\hline & & Delivery tools & Inclusion (equity) \\
\hline $\begin{array}{l}\text { Various international } \\
\text { projects and NGOs } \\
\text { hire their own staff } \\
\text { (numbers are not re- } \\
\text { corded), without much }\end{array}$ & $\begin{array}{l}\text { Varies by project focus; not } \\
\text { standardized; no continuing ed- } \\
\text { ucation; absent or inadequate } \\
\text { regulatory incentives. }\end{array}$ & $\begin{array}{l}\text { More tradition- } \\
\text { al, less ICTs } \\
\text { (information and } \\
\text { communications } \\
\text { technologies). }\end{array}$ & $\begin{array}{l}\text { Donor-funded projects } \\
\text { often target youth and } \\
\text { women. }\end{array}$ \\
\hline
\end{tabular}

100-831 farmers per extension worker in public sector and 42642 small producers per extension worker in private sector.

Extension department is largest organization employing 14,092 field-level extension agents, with each responsible for 900 to 2,000 farm families.

State-level extension has mandate to serve at the municipality level while civil society is encouraged to seek funding competitively; 20,000 agents.

Unknown.
Significant efforts to train and upskill extension staff; Chile, Nicaragua, El Salvador, and the Dominican Republic had continuing education; Guatemala none. Salaries range from around US $\$ 9,000$ in Paraguay to just under US\$35,000 in Argentina. General lack of baseline information, monitoring and evaluation, and feedback systems on performance of extension.

Typically hold diplomas from one of the 11 agricultural training institutions. Training tends to be technical with focus on cropping systems. Public salaries relatively high.

Strong training on participatory methodologies and service delivery, such as providing advice and support on short-term credit; ability to reach different ages and genders weak.

Has Directorate of Agricultural Training and Animation.
Increasing diversity, especially ICT.

Some efforts to explicitly include marginalized groups.
Wide variety but informal channels and information sources such as agrodealers important.

Focus on participatory methods, agroecology, sustainable farming, organic farming, and high-value agriculture.

Unknown.
Training on gender usually only in projects.

Policy focuses on marginalized groups and pays attention to age and gender.

National gender policy addresses inequalities. 
TABLE 3.1 Continued

Governance structures

\begin{tabular}{|c|c|c|}
\hline & & \\
\hline Country or region & Providers and policies & Financing and budget \\
\hline $\begin{array}{l}\text { Cambodia (Ke and } \\
\text { Babu [2018]; } \\
\text { INGENAES [2016k]) }\end{array}$ & $\begin{array}{l}\text { Pluralistic with strong } \\
\text { public sector. }\end{array}$ & $\begin{array}{l}\text { Centralized funding but } \\
\text { often inadequate to } \\
\text { cover the needs. }\end{array}$ \\
\hline & $\begin{array}{l}\text { Policies include some } \\
\text { attempts to modernize } \\
\text { and update extension. }\end{array}$ & \\
\hline $\begin{array}{l}\text { Democratic Republic } \\
\text { of the Congo (see } \\
\text { Chapter } 8 \text { ) }\end{array}$ & $\begin{array}{l}\text { Pluralistic with public } \\
\text { provision and many } \\
\text { nongovernmental } \\
\text { providers. }\end{array}$ & $\begin{array}{l}\text { Low government } \\
\text { funding; major donor- } \\
\text { funded projects on } \\
\text { extension. }\end{array}$ \\
\hline & No policy. & \\
\hline $\begin{array}{l}\text { Ethiopia (INGENAES } \\
\text { [2016j]; see Chapter 6) }\end{array}$ & $\begin{array}{l}\text { Strongly state-led } \\
\text { provision with some } \\
\text { NGOs, producer orga- } \\
\text { nizations, and donor } \\
\text { projects. }\end{array}$ & $\begin{array}{l}\text { Major government } \\
\text { investments; largely } \\
\text { public extension; some } \\
\text { projects, NGOs, private } \\
\text { sector. }\end{array}$ \\
\hline
\end{tabular}

Few organizations have incentive systems for good performance.

Policy exists.

Ghana (INGENAES

[2016i])

Pluralistic with public provision and many nongovernmental providers and projects.

Almost entire budget comes from government of Canada (personal communication, Coordination

Department of Agricultural Extension is responsible.

Policy exists (2001).

Guatemala (Chaisson-

Pluralistic.

April 8, 2019).

Cardenas [2019];

INGENAES [2016h])

No policy.

Most funds for public extension come from the National General Fund; decentralization efforts are reviving creation of 340 municipal-level extension agencies.

Guinea (MacNairn
[2017])

Pluralistic with public provision and many Government and Incentives for good performance of staff but limited facilities demotivate.

Need for coordination due to number of providers.

Unknown. nongovernmental prodonors.

Variable depending on external resources.

Donors and govern- Unknown.

Haiti (Goertz [2016])

No policy.

Weak public sector with many projects ment.

and nongovernmental actors.

No policy. 


\begin{tabular}{llll} 
& Management style (including & \multicolumn{2}{c}{ Advisory methods } \\
\cline { 3 - 4 } monitoring and evaluation, & Delivery tools & Inclusion (equity) \\
\hline $\begin{array}{l}\text { Majority of staff at the } \\
\text { provincial level with }\end{array}$ & $\begin{array}{l}\text { Training extension staff } \\
\text { recognized as imminent need, }\end{array}$ & Focus on ICT slow- & No clear policy on \\
limited number at & $\begin{array}{l}\text { but has not supported with } \\
\text { district level. }\end{array}$ & & inclusiveness. \\
adequate funding. & & &
\end{tabular}

Large number of extension agents, but no operating funds.

Good extension agent ratio; still face major capacity challenges; supply-driven extension.

Pluralistic from all sectors.

Extension has services in 19 of 22 departments, and Ministry of Agriculture estimates that half of municipalities have extension coverage.

800 public agents.

Mainly NGO-provided but government also.
Largely no training; postconflict country; public salaries extremely low.

Training mainly technical; financial rewards, educational opportunities, certificates, and promotions for good performance.

Government is doing reskilling with help of Canadian universities.

Eight-month Rural Extension Certificate Program designed to support extension in strategy, production technology, environment, socioeconomics, food security, and nutrition.

Five national agricultural education and training centers give diplomas. No incentives for public agent performance.

World Bank recommends rehabilitation of vocational schools and farmer field education to drive demand and supply of extension.
More traditional, No. less ICTs.

Variety including group approach, visual methods.

Trainings organized for women and youth.

\section{Multiple.}

Unknown.

Unknown.

Poor gender equality, some donor projects focus on indigenous people; previous projects focused on youth.

Multiple.

Several projects target women and youth.

Unknown.

Poor on gender equity. 
TABLE 3.1 Continued

\begin{tabular}{|c|c|c|c|}
\hline \multirow[b]{2}{*}{ Country or region } & \multicolumn{3}{|c|}{ Governance structures } \\
\hline & Providers and policies & Financing and budget & Coordination \\
\hline $\begin{array}{l}\text { Honduras (Valenzuela } \\
\text { and Saavedra [2017]; } \\
\text { Williams [2016]) }\end{array}$ & $\begin{array}{l}\text { Pluralistic. } \\
\text { No extension policy; } \\
\text { agricultural policy } \\
\text { guided by 2004-2021 } \\
\text { State Policy for the } \\
\text { Agri-Food Sector } \\
\text { and Rural Areas and } \\
2014-2018 \text { Govern- } \\
\text { ment Strategic Plan } \\
\text { Everyone's Plan for a } \\
\text { Better Life. }\end{array}$ & $\begin{array}{l}\text { Government and } \\
\text { donors. }\end{array}$ & $\begin{array}{l}\text { Pluralism results in frag- } \\
\text { mented delivery with little } \\
\text { coordination and weak } \\
\text { leadership. }\end{array}$ \\
\hline $\begin{array}{l}\text { India (Babu and } \\
\text { Shishodia [2018]) }\end{array}$ & $\begin{array}{l}\text { Very pluralistic and } \\
\text { decentralized with } \\
\text { strong public provision, } \\
\text { producer organiza- } \\
\text { tions, private sector, } \\
\text { and many nongovern- } \\
\text { mental providers. } \\
\text { Policy exists. }\end{array}$ & $\begin{array}{l}\text { Increased funding } \\
\text { to human resource } \\
\text { development but likely } \\
\text { to devolve to a state } \\
\text { level. }\end{array}$ & $\begin{array}{l}\text { Coordination very poor due } \\
\text { to multiple roles extension } \\
\text { agents play. }\end{array}$ \\
\hline $\begin{array}{l}\text { Kenya (INGENAES } \\
[2016 \mathrm{~g}])\end{array}$ & $\begin{array}{l}\text { Strongly pluralistic } \\
\text { and decentralized } \\
\text { with many public and } \\
\text { private players. } \\
\text { National Agriculture } \\
\text { and Livestock Exten- } \\
\text { sion Policy (2000). }\end{array}$ & $\begin{array}{l}\text { Government (now } \\
\text { devolved to the county } \\
\text { level) and donors; } \\
\text { many NGOs and } \\
\text { private sector. }\end{array}$ & $\begin{array}{l}\text { Agricultural Sector Coordi- } \\
\text { nation Unit. }\end{array}$ \\
\hline $\begin{array}{l}\text { Liberia (Sigman } \\
\text { [2017]; INGENAES } \\
\text { [2016f]; McNamara, } \\
\text { Swanson, and Simpson } \\
\text { [2011]) }\end{array}$ & $\begin{array}{l}\text { Weak government pro- } \\
\text { vision as well as many } \\
\text { projects and some } \\
\text { private companies. } \\
\text { Policy exists (2012). }\end{array}$ & $\begin{array}{l}\text { Government but very } \\
\text { constrained. }\end{array}$ & $\begin{array}{l}\text { Though not functional, } \\
\text { policy stipulates coordina- } \\
\text { tion platform at national, } \\
\text { county, and district } \\
\text { levels, managed through } \\
\text { Agricultural Coordinating } \\
\text { Committee. }\end{array}$ \\
\hline $\begin{array}{l}\text { Malawi (Cai [2017]; } \\
\text { INGENAES [2016e]; } \\
\text { Simpson, Heinrich, and } \\
\text { Malindi [2012]; see } \\
\text { Chapter 7) }\end{array}$ & $\begin{array}{l}\text { Very pluralistic and } \\
\text { decentralized with } \\
\text { strong public provision, } \\
\text { producer organiza- } \\
\text { tions, private sector } \\
\text { and many nongovern- } \\
\text { mental providers and } \\
\text { projects. } \\
\text { Currently revising } \\
\text { policy. }\end{array}$ & $\begin{array}{l}\text { Low government } \\
\text { funding; major } \\
\text { donor-funded projects } \\
\text { on extension; large } \\
\text { farmer-based orga- } \\
\text { nizations with own } \\
\text { extension agents. }\end{array}$ & $\begin{array}{l}\text { Highly developed struc- } \\
\text { tures to coordinate and } \\
\text { plan. }\end{array}$ \\
\hline
\end{tabular}


Limited levels of human resources, no new recruitment since 1998 , although this is changing with reforms in some states.

5,470 in 2013 (before
devolution).

Unknown.

Regular training is part of the extension system, but the curriculum has not kept up with changing needs of the farmers. A new national curriculum is being developed.

Mainly university graduates, generally agricultural engineers; most organizations provide continuing education; incentives used by $66 \%$ of organizations; government salaries low.

\begin{tabular}{ll}
\multicolumn{2}{c}{ Advisory methods } \\
\hline Delivery tools & Inclusion (equity) \\
Farmer field & Some organizations \\
schools most & focus on gender, youth, \\
common. & and marginalized \\
& populations.
\end{tabular}

Large number of government extension agents, although with some vacancies. to farmer ratios from $1: 1,000$ to $1: 5,000$

\section{Large focus on ICTs combined with traditional methods and farmer field schools.}

Various.

Various.

\begin{abstract}
Two-year National Agriculture Diploma Program; nongovernment workers have higher salaries and more incentives such as training, equipment, and transportation.
\end{abstract}

Some trainings mainly from donor projects; farmer-to-agent and farmer-to-lead farmer ratios used as main extension performance indicators. including radio programming,
Management style (including monitoring and evaluation,

Variety of methods, group approaches, lead farmer, model village, among others.

\begin{abstract}
Gender-sensitive programs at the local level; state extension system focuses on smallholders, but richer and better educated farmers seem to capture most of the benefits.
\end{abstract}

Policy identifies several approaches and methods that target rural women.

Gender-sensitive practices and culture within extension and wider agricultural community.

Policies on gender exist; strong donor and NGO efforts for gender equality. 
TABLE 3.1 Continued

Governance structures

\begin{tabular}{llll}
\cline { 2 - 4 } Country or region & Providers and policies & Financing and budget & Coordination \\
\hline Mali (DLEC [2018]; & Pluralistic and govern- & Government and & National Directorate of \\
INGENAES [2016d]) & ment led. & donors. & $\begin{array}{l}\text { Agriculture responsible to } \\
\text { coordinate. }\end{array}$ \\
& No extension policy, & &
\end{tabular}

but various related pol-

icies in the agricultural

sector.

Mozambique (Cuangara and Thompson [2018]; INGENAES

[2016l])

Nepal (Suvedi and

McNamara [2012])

Nigeria (Huber, Davis, and Lion [2017])

Rwanda (MacNairn [2018]; INGENAES [2016a])

Senegal (Franzel, Ndiaye, and Tata [2018]; INGENAES [2015])
Very pluralistic and decentralized with public provision, producer organizations, private sector and many nongovernmental providers and projects.

New Extension Master Plan 2018-2027 was under development (V. Parkinson, personal communication, 2017).

Government-led but with many projects and nongovernmental organizations.

No policy.

Decentralized with a number of government and nongovernment providers.

Policy in development.

Strongly government led but with many projects and nongovernmental providers.

Policy exists (2009).

Government, including national development agencies; farmer organizations and projects.

Government and donors.

National budget and donors through basket funding.

Limited; researchextension coordination takes place through periodic reviews.
Federal government and some states.

Government led with donor support, many NGOs.

Parastatal led by national government with producer organizations, private sector, and local government.
Had strong system when supported by the World Bank.

Research and extension are merged.

Weak, especially at the local level; in theory take place through researchdevelopment committees under extension in each region.

No extension policy. 


Capacity (staffing)
Public staff were 839
in 2009 and are major
providers by numbers
and geographic and
technical coverage
(women were $10-25$
percent); staff are
rapidly aging.

1,304 public agents $(1$ public agent per 3,000 households); some incentives.
Management style (including monitoring and evaluation, incentives, training)

Rural Polytechnic Institute of Training and Applied Research-certificates up to MSC level; insufficient resources to perform work (transport, equipment).

Very weak foundational and continuing education; public sector cannot compete with nonstate salary levels; public sector has performance indicators.
4,974 technical agricultural and 4,050 livestock staff.

7,000 public agents, $28 \%$ female

\section{2,500 farmer field} school facilitators and 14,200 farmer promoters.

500 but $24 \%$ vacancy rate in 2017.
Adequate infrastructure but need to strengthen market, group development skills; M\&E weak; $60-70 \%$ district budget to salaries.

Diploma or BSc; many agricultural institutes exist; no performance-based management system for extension staff.

Field school facilitators have up to secondary level; performance contracts ensure accountability.

Field agents have diplomas; many NGO staff have BSC or MSc; access to vehicles; performance management systems absent in the public sector.

\begin{tabular}{ll}
\multicolumn{2}{c}{ Advisory methods } \\
\hline Delivery tools & Inclusion (equity) \\
\hline $\begin{array}{ll}\text { Various delivery } & \text { Some projects target } \\
\text { tools. } & \text { women and youth. }\end{array}$
\end{tabular}

Various.

Female agents number $16 \%$ of public agents. $\begin{array}{ll}\text { Various including } & \text { Mainly generalist } \\ \text { mass media. } & \text { approach; frontline } \\ & \text { workers mainly men. }\end{array}$

Various including Women have low one-stop shops.

Farmer field schools and farmer promoters predominate.

Various.

Women appear underrepresented among staff and farmer trainers. 
TABLE 3.1 Continued

Governance structures

\begin{tabular}{llll}
\cline { 2 - 4 } Country or region & Providers and policies & Financing and budget & Coordination \\
\hline $\begin{array}{l}\text { Sierra Leone } \\
\text { (INGENAES [2017]) }\end{array}$ & $\begin{array}{l}\text { Weak government } \\
\text { provision with many } \\
\text { projects. }\end{array}$ & $\begin{array}{l}\text { Various with high } \\
\text { donor involvement. }\end{array}$ & $\begin{array}{l}\text { Extension division coordi- } \\
\text { nates delivery. }\end{array}$ \\
& No policy. & &
\end{tabular}

Tajikistan (INGENAES

[2018]; Dosov [2018])

Tanzania (INGENAES [2016b])

\section{Uganda (INGENAES}

[2016c]; see

Chapter 5)

Viet Nam (Ngan and Babu [2018])
Many nongovernmental; weak public and private.

No policy, only National Development Strategy.

Very pluralistic and decentralized with public provision, producer organizations, private sector and many nongovernmental providers and projects.

No extension policy; National Agriculture Policy (2011).

Very pluralistic and decentralized with public provision, producer organizations, private sector and many nongovernmental providers and projects.

Policy exists.

Pluralistic and government led.

Attempting to restructure agriculture.
Donor-dependent;

majority NGOs; also government, research, academia.

Strong public role with donor funding; also NGOs.

Unknown.

Limited.

Pluralistic with donor

New Single Spine Agriculfunding, many NGOs tural Extension System has and private providers. strong collaboration with nongovernment actors.

Following decentralization, increased local funding.

Coordination structures exist and function reasonably well. 
Officers typically subject matter specialists with limited access to resources.

In 2012, 10,891 extension officers, 6,925 for crops and 3,966 for livestock; $75 \%$ men.
Centralized system of professional training and capacity building.

Unknown.

In 2017 the government launched Guidelines, Standards, Code of Ethics and Process for Registration and Accreditation of Extension Service Providers.

Attempt to enhance training

High turnover of staff in the extension system. from 1995 to 2015; low incentives for public agents.
Various.

Delivery tools Inclusion (equity)

Training and Attempts to mainvisit, innovation platforms, farmer field schools, agricultural business centers, farmer-based organizations. stream gender equity and inclusion, but limited voice for women and information access. Agenda for Prosperity five-year (2010-2015) strategy promoted empowerment of girls and women.

Cultural beliefs value men over women; no specific strategies; some programs focused on women.

Various; individual Women have limited and group contact, access to land and farmer field schools important. credit to purchase modern farming inputs.

\section{Village Agent} Model, farmer field Many programs target schools, others.
Use of ICT limited. No; women have less Still heavy reliance access to extension. on field demonstrations. 
TABLE 3.1 Continued

\begin{tabular}{llll}
\hline & \multicolumn{3}{c}{ Governance structures } \\
\cline { 2 - 4 } Country or region & Providers and policies & Financing and budget & Coordination \\
\hline $\begin{array}{l}\text { Zambia (Burrows, Bell, } \\
\text { and Rutamu [2017]) }\end{array}$ & $\begin{array}{l}\text { Pluralistic with public } \\
\text { provision, producer } \\
\text { organizations, private } \\
\text { sector, and many } \\
\text { nongovernmental pro- } \\
\text { viders and projects. }\end{array}$ & $\begin{array}{l}\text { Pluralistic; major } \\
\text { problem of underfund- } \\
\text { ing (up to one-third of } \\
\text { positions go unfilled as } \\
\text { a result). }\end{array}$ & $\begin{array}{l}\text { Coordination } \\
\text { meetings to harmonize } \\
\text { extension services with } \\
\text { other actors. }\end{array}$ \\
& $\begin{array}{lll}\text { No; development strat- } \\
\text { egy based on Vision }\end{array}$ & & \\
& $\begin{array}{l}\text { 2030 and 6th National } \\
\text { Development Plan } \\
\text { (revised in 2013). }\end{array}$ & & \\
Zimbabwe (Mwakiwa & $\begin{array}{l}\text { Public, private, and } \\
\text { nongovernmental proj- } \\
\text { [2017]) }\end{array}$ & Donor support with \\
limited government. & Previous mechanisms not \\
ects provide services. & & \\
& No policy exists. & & \\
\hline
\end{tabular}

Source: Author's compilation based on the various chapters in this book and their earlier, longer versions.

Viet Nam's Ministry of Agriculture and Rural Development led all activities of the Department of Agriculture and Rural Development and the National Center for Extension (Ngan and Babu 2018), guiding provincial extension centers and District People's Committee, which manages district extension stations, commune extension staff, and village extension collaborators. In Africa extension in Ethiopia continues to be heavily government run, although the country is highly committed to financing and reforming its extension system as a cornerstone of its agricultural transformation agenda. Rwandan extension is also heavily government run yet pluralistic.

Pluralism (the presence of many types of extension providers from different sectors), however, is the norm in all the countries to varying degrees, with government, private sector, and civil society all providing extension services. Some countries in Latin America that did away with public-sector extension several decades ago (hoping that the private sector would fill the gap) are beginning to fund public services once more (for example, Colombia, Ecuador, and Honduras). Countries in Latin America now have a mix of public and private extension providers: local municipalities, nongovernmental organizations, and universities. Although more organizations are providing extension services, the country cases show that pluralism of service delivery is far from being complete, with elements of competition across different 
Management style (including monitoring and evaluation, incentives, training)

University of Zambia's School of Agricultural Sciences and agriculture training institutes train staff as general agricultural practitioners.
Advisory methods

\begin{tabular}{|c|c|}
\hline Delivery tools & Inclusion (equity) \\
\hline $\begin{array}{l}\text { Various, including } \\
\text { study circles, lead } \\
\text { farmers. }\end{array}$ & $\begin{array}{l}\text { Women often do } \\
\text { not own or control } \\
\text { productive resources, } \\
\text { are excluded from } \\
\text { decision-making pro- } \\
\text { cesses, and are less } \\
\text { likely to benefit from } \\
\text { services. }\end{array}$ \\
\hline
\end{tabular}

Training of trainers; training and visit; lead farmer; group approach; demonstrations; field days; media.
No framework to deal with gender; women underrepresented in extension force.

\begin{abstract}
ers, $84.5 \%$ have certificates, in suboptimal skill sets; high turnover.

$0.4 \%$ have $\mathrm{MSc} ; 3.8 \%$ have
\end{abstract} employed by government. 
programming has been shown to be effective in improving access to quality extension services. These could be intensified for other technologies and advisory methods and could be expanded to other countries.

Extension in India has become increasingly pluralistic over the past two decades (Babu and Shishodia 2018), with a deliberate move by government in 2011 toward decentralized provision of extension with the complete rollout of the Agricultural Technology Management Agency and the rise in the role of private-sector and nongovernmental organizations in extension. Privatesector extension provision in India faces many challenges. The reach of private extension remains limited to wealthier commercial farmers who can afford to pay for it. And, although productivity gains through private extension services received by smallholder farmers are not uncommon, there are many cases of exploitation of farmers by private companies providing extension in India (Zhou and Babu 2015). Nonetheless, in other settings private extension, often bundled with other input provision and marketing, frequently through contract farming schemes, has been effective in delivering relevant and useful knowhow to farmers and increasing their production and incomes (Ragasa, Lambrecht, and Kufoalor 2018; Ruml, Ragasa, and Qaim 2019; see Chapters 4 and 7). These findings highlight the need to monitor and harmonize extension messages and to develop farmers' collective negotiation skills and bargaining power from them to work as equal partners with private companies.

\section{Financing}

Countries finance their extension services from national or subnational budgets, levies and taxes, and development aid as well as by paid services from the private sector. Countries that struggle to fund their extension systems include most of those in Africa and Central Asia. According to Dosov (2018), the lack of policies or regulations that specifically provide guidance or define the rules of a national extension system means there are limited options for national governments to invest in extension. Donors often step in, which, if not well-regulated, may lead to the lack of cohesion and a duplication of services. What government funds do exist go mainly to pay salaries, leaving litthe for operational expenses. Although donors and international NGOs cover operating funds for extension, often working with government extension agents, their projects are short-lived and largely uncoordinated. Thus government funding is required for sustainability and for much needed coordination and monitoring for these various efforts.

The exception is Ethiopia and Rwanda, which have strong government commitment to agriculture and to extension to achieve their development 
objectives. These two countries strongly fund the sector as well. This does not preclude donor funding, but Ethiopia and Rwanda lead the donor working groups to coordinate financing and provision of services. Greater diversity in funding sources was seen in Argentina, Chile, Colombia, and Ecuador as the Latin American region has experimented with new models and orientations in extension implementation, matched with investments in the reform of extension systems. In Colombia the sources of financing were diverse: 29 percent of the organizations received resources from the national government; 19 percent from departmental governments; 35 percent from municipal governments; 14 percent from producer payments; 11 percent from local donations; and 14 percent from development aid. In Chile's Technical Assistance Service the national government contributed 70 percent, while the remaining 30 percent is financed by the producers (Preissing et al. 2018). Argentina had considerable self-financing directly or indirectly from producers, but occasionally they receive external financing from national programs (Preissing et al. 2018).

Ecuador had a diverse funding mix, based on the types of programs and initiatives. Public programs depended 100 percent on the national budget. Decentralized governments differed; for example, the Provincial Government of Tungurahua depended 50 percent on government resources and 50 percent on international cooperation for extension provision (Preissing et al. 2018). India also exhibits some funding diversity. However, gaps still exist. Nearly 45 percent of total funds under the Agricultural Technology Management Agency (ATMA) - the major public-sector approach to extension, implemented through state-level funded extension personnel-was spent on farmer-oriented activities such as organizing training programs, conducting demonstrations, exposure visits for farmers, and mobilizing farmers to form farmer interest groups or self-help groups (Babu and Shishodia 2018). At the same time, the traditional state extension agents continued to be employed to implement state-level subsidy schemes. The sustainability of funding for ATMA in the long run is still debated, as there are signs that the central government will transfer the full responsibility of ATMA to the states at some time in the future (Babu and Shishodia 2018).

Decentralization has been tried in almost all of the countries studied in this book as a way to increase accountability by bringing the services closer to the clientele. However, the legal transfer of responsibilities for agricultural services is often not matched by sufficient fiscal decentralization, therefore continuing dependence on the transfer of funds from the central government undermines the autonomy of local governments. Where such transfers have been reduced and taxes and revenues by the local government remain 
meager, the promises of decentralization often are not realized. For example, attempted reforms toward a district-level agricultural extension services system in Malawi lack the resources and capacity to coordinate different service providers and engage with farmers (see Chapter 7 on Malawi). This is also consistent with public expenditure studies in other countries-for example, in Ghana analysis of district budgets over time indicates that total average agricultural expenditures at the subnational level decreased from 11 percent to 6 percent of spending between the onset of decentralization in 2012 and 2015 (Resnick 2018).

\section{Institutional Linkages and Coordination}

The coordination issues tend to follow the policies and financing trends just discussed. Those with no policies or weak policies and many different types of funding, especially donor and project funding, tend to struggle with coordination and linkages. Those with strong policies and strong government financing tend to have better coordination and linkages. A major challenge has been the poor institutional linkage between the formal research, education, and extension systems as well as coordination within extension (Babu and Shishodia 2018; Dosov 2018; Preissing et al. 2018). Coordination has been a major issue given that many different organizations are providing extension today and there is weak institutional capacity to coordinate them. In Colombia, for example, 38 percent of the organizations surveyed had weak links with other organizations; 30 percent had moderate links; and 20 percent had close links. However, stronger links occurred with local government agencies and microcredit banks and institutions (31 percent) (Preissing et al. 2018). Except for a few cases, such as in Argentina and Brazil, which had formal institutional cooperation agreements and assistance, incentive and mechanisms for exchanges among researchers and extension services are weak and nonexistent in Latin America (Preissing et al. 2018).

Malawi is well known as a country with a multitude of projects, donors, and nongovernmental organizations as well as government commitment to extension. Extension in Malawi (see Chapter 7) is dominated by the public extension system, although there is a rich diversity of civil society, nongovernmental agencies, and private-sector companies implementing extension projects as well. The Ministry of Agriculture, Irrigation and Water Development (MoAIWD) is decentralized, yet translation of the research outputs into tangible benefits for farmers will require improved engagement of district-level actors. An Agricultural Extension Policy Implementation Guide was adopted in 2004 (Malawi, MoAIWD 2004) to implement the national extension 
policy. It also aims to guide the District Agricultural Extension Services System (DAESS) in coordination among the many actors. However, considerable investment in institutional capacity is needed before coordination can be improved. The National Agriculture Content Development Committee (NACDC), instituted in 2014, is a good start; if continued and funded, the NACDC should strengthen coordination.

In India's extension system, coordination of extension professionals in various entities has been a long-standing challenge (Babu and Shishodia 2018). Staff of farm science centers report to central government, state government, and NGOs, which manage the centers. In the same state some of the farm science centers are run directly by central government staff, while others are run by state agricultural university staff, and yet others by NGOs. There is hardly any coordination among them, even though they may be in the same agroecological zones. Furthermore, there is a high level of disconnect between the farm science centers and the state extension functionaries. Linkages between the Indian Council for Agricultural Research—an important information source for extension workers - and the state departments of extension remain weak (Babu and Shishodia 2018). Although farm science centers exist for each district to translate research into adoptable technologies, coordination of state extension personnel in this effort remains weak, even after the introduction of the decentralized Agricultural Technology Management Agency (ATMA) model.

Some stronger links were seen in Argentina and Uruguay. Argentina showed a high degree of linkages and institutional agreements (Preissing et al. 2018), with most links formalized by cooperation agreements. The strongest links were with universities, local or municipal government agencies, and research centers; more moderate links were with technical training services and NGOs; and the weakest links were with cooperative organizations, banks and credit institutions, and input suppliers. In Uruguay there were strong links between actors, especially at the local level and occasionally in an informal way. These links developed because of mutual knowledge of issues at the local level. Chile's Local Development Program is linked to few entities, and the perception is that the links are mostly moderate to weak with the strongest established with government agencies and municipalities.

To promote intersectoral collaboration and checks, multistakeholder panels and innovation platforms have been formed in various countries to help address information gaps on preferences and demands for extension services and on performance of providers. Although many of these platforms function poorly due to lack of motivation and limited capacity of service providers 
to respond to demands of rural communities, newer forms of innovation platforms that focus on market access and center on specific value chains have been successful in some cases (Ragasa, Badibanga, and Ulimwengu 2016).

Other promising mechanisms are available that can contribute to improving coordination, transparency, and accountability in extension service provision. In Ethiopia, Digital Green's Connect Online-Connect Offline platform, which regularly collects data and automatically computes relevant statistics on adoption and yields, provides relevant and timely data for decision-making and programming (see Chapter 6). In Rwanda an approach combining elements of performance-based contracts for various actors, consultative platforms for greater accountability, earmarked funding, and capacity strengthening at all levels is successfully improving adoption and yields (MacNairn 2018). Three-party performance contracts between Rwandan district officials, the Rwanda Agricultural Board, and farmer field school facilitators' cooperatives are helping monitor the progress of field school facilitators. This approach is combined with the imihigo system, a traditional consultative process for demand articulation and accountability. Combining these different elements, by earmarking funding and creating metrics for successful service delivery that go beyond budgeted expenditures or input indicators, coupled with receipt of frequent updates on these priority metrics through ICT, service providers and decisionmakers at all levels can address problems in real time.

\subsection{Capacity}

\section{Human Resources}

Most of the case studies report human resources as one of the constraints to increasing effectiveness of the extension system. In general, capacities include staff skills, the infrastructure and equipment to carry out the job, as well as foundational and continuing education for extension personnel. Extension capacity is not only at the level of the extension officials or frontline workers; it also applies to extension organizations at different levels and the role they play in the agricultural innovation system. Extension capacity at the personnel level includes quantity and quality of those officials and staff providing extension. This section looks first at the human resources (number or coverage and type of staff) and then their foundational and continuing education.

In Latin America extension coverage ranged from 100 to 831 farmers per extension worker in the public sector and between 42 and 642 small 
producers per extension worker in private-sector programs (Preissing et al. 2018). According to Preissing and colleagues (2018), 55 percent of the Central American extension staff were technical and professional extension workers in the organizations interviewed, and 45 percent were support staff. The public sector had the largest number of technicians and extension professionals as well as support staff (Guatemala had a 75:25 ratio and Nicaragua 70:30) (Preissing et al. 2018).

In Africa south of the Sahara, the farmer-to-extension agent ratios are much higher than in Latin America, and there are also high vacancy rates of government extension agents' positions. In Senegal a high vacancy rate (24 percent in 2017) has been a chronic problem due to lack of funds to pay salaries of new staff (Franzel, Sinja, and Simpson 2018). The total number of extension agents across sectors in Senegal was approximately 500, not counting all the managers.

Ethiopia has invested significantly in its human and physical capital in recent years. The country has a significant extension force and infrastructure in the form of farmer training centers at many of the lowest administrative units (Chapter 6). In addition to the workforce of some 47,500 extension agents, there are roughly 7,000 subject matter specialists and 4,000 supervisors employed in the public extension system in district and regional offices. Extension agents in Ethiopia are generally trained in crops, livestock, or natural resource management at one of the Agricultural Technical and Vocational Education and Training (ATVET) colleges. All public extension agents have postsecondary education, and they generally have a good mix of expertise on crops and livestock production and natural resources management.

In some countries in Asia coverage is also an issue. In India most state departments function with limited levels of capacity in terms of human resources, with no new recruitment since 1998 (Babu and Shishodia 2018). This overburdens the existing staff and prevents them from increasing their capacity and updating their knowledge. Only 20 percent of staff are university graduates. The ratio of staff to farmers varies widely across the states and is particularly low in remote areas in the north and east of the country. Increased system, individual, and institutional capacity are needed to increase the productivity of crops and the sustainability of production systems. In Viet Nam about 20 percent of extension workers retire or resign each year, equivalent to a loss of 5,600 staff a year. Therefore, the intake needs for the extension system is 5,000 people a year. However, Viet Nam is experiencing a shortage of human resources as the number of students enrolled in agricultural extension schools is declining (Ngan and Babu 2018). 
Capacity of existing staff to be effective on the job is a further problem. Along with the quantity of extension workers, there is also a shortage of quality. Training levels for extension staff range from diplomas received from agricultural training institutes (Bangladesh, Ethiopia, Senegal) up to MSc or BSc degrees in agriculture for managerial staff in Senegal (Franzel, Ndiaye, and Tata 2018). Some countries provide continuous education to extension agents, particularly within donor projects, but these are largely uncoordinated (see Chapter 7 on Malawi and Chapter 8 on the Democratic Republic of the Congo). An exception, Chile has a well-supported process for continuous training of service providers, and in Colombia, 25 percent to 35 percent of the Municipal Units of Agricultural Technical Assistance technical staff had access to continuous training activities, while 60 percent to 75 percent of consulting firm and NGO staff had access to training programs in universities and other courses promoted by the Ministry of Agriculture and Rural Development (Preissing et al. 2018).

Furthermore, training is not always in all the relevant areas. Extension staff may have adequate technical backgrounds (albeit with limited hands-on applications during training) but are weak on the so-called functional or "soft" skills. In Tajikistan, for instance, agricultural advisers were often technically trained and well-oriented, but they needed commercial expertise - that is, skills and attitudes that are necessary in a market economy (Dosov 2018). These advisers needed knowledge and skills of how small farmers can enhance and diversify their farming systems. They lacked skills for organization and operation of self-help activities and group work and cannot help groups with marketing. Agricultural advisers also needed skills and equipment to work with information and communications technologies to work more costeffectively, had limited access to relevant market information, and lacked the ability to use modern tools for decision-making (Dosov 2018). Assessments in Honduras and Malawi found limited focus on functional skills, such as group development, communication, or entrepreneurship (Cai 2017; Valenzuela and Saavedra 2017).

Many countries use local "farmer extensionists" to bolster extension services and help to increase the reach of extension more sustainably. For instance, to deal with Cambodia's extension officers' low capacity, village-level para-extension workers are employed who work with the government extension providers (Ke and Babu 2018). Viet Nam has about 20,000 grassroots volunteer extension workers at the commune and village levels (Ngan and Babu 2018). Similarly, Senegal uses farmer trainers, who tally about 9,100 (including community nutrition volunteers) (Franzel, Ndiaye, and Tata 2018). Almost 
all extension agents in Ethiopia (Chapter 6) used model farmers who, in theory, each reach five more farmers, to expand their reach. In Malawi official figures show a ratio of one lead farmer to six farmers (see Ragasa et al. 2019; Chapter 7 on Malawi).

There is, of course, a trade-off between quality and quantity of these efforts. Many short-term projects may temporarily train farmer extensionists, but it is not always institutionalized for the longer term as in the case of Peru, where training efforts are focused on building capacities of the rural promoters (Preissing et al. 2018). In addition to adequate training and capacity building, community ownership, recognition and support, as well as government extension agents' support, are often lacking, which continue to demotivate lead farmers, reducing their effectiveness and impact in the community (see Ragasa 2019; see Chapter 7 on Malawi). In Uganda even simple signposts to signal the presence of lead farmers in the community could make a difference in the impact of the program (Behaghel et al. 2018). Farmers reported that the farmer trainers with signposts were more knowledgeable about dairy farming than those without, indicating that this variation increased their credibility; it may also have enhanced their motivation (Behaghel et al. 2018). Registration and certification efforts are just getting under way in many countries. Uganda has been undergoing a process of registration and accreditation of agricultural extension and advisory service providers, along with guidelines and standards for agricultural extension services (see Chapter 5). Except for efforts in Peru, little has been done to certify the skills of extension workers or producer leaders at the community level in other South American countries.

\subsection{Management}

Organizational management in extension includes the management style of extension organizations, procedures carried out, incentives and methods of performance assessment of individual agents, and monitoring and evaluation of the services. Staff salaries for extension agents are usually similar to those of other different public-sector agencies but considerably lower than those in research (for example, in Senegal; see Franzel, Ndiaye, and Tata 2018). Nongovernmental and private-sector extension agent salaries are generally higher. The variation between public- and private-sector salaries affects many African countries and tends to lead to high staff turnover in the public sector. The public sector in Mozambique, for instance, is unable to compete with the private sector and NGOs for salaries, and many extension staff leave 
the government for better paid salaries in the private sector. The Ministry of Agriculture must constantly train new staff to fill the gap. Incentive policies to retain staff in the public sector do not exist or are nonfunctional (Cuangara and Thompson 2018).

However, public extension agents in Bangladesh were relatively well paid, receiving between US $\$ 450$ and US $\$ 500$ per month on joining and US\$630 per month with five years of service (Huber and Davis 2017). Similarly, in Central America salaries of extension workers fluctuated between US\$5,400 and US $\$ 12,000$ per year in public institutions and were lower than private and nongovernmental organizations (Preissing et al. 2018). Salaries for South American public-sector staff are shown in Figure 3.1.

Beyond salaries, incentive systems also affect the performance of public and private extension staff. Many have no incentives for public extension agent performance (for example, Guinea; see MacNairn 2017). The Ethiopian extension system provided rewards and prizes for good performance of their staff, such as financial rewards, educational opportunities, certificates, and promotions. In fact, 40 percent of extension agents said they received some reward for good performance in the past three years (see Chapter 6). However, promotion, benefits, and allowances seem to be not the same for all. Despite recent efforts to clarify the extension agents' specific roles and tasks, the amount and type of work they are expected to perform is extensive and continually increasing, leaving agents overburdened and poorly prepared to carry out regular extension activities. Despite a well-staffed extension system with incentives, the organizational management of extension workers in Ethiopia remains a challenge (Chapter 6). Extension agents in Ethiopia have been overburdened by activities beyond their regular mandates, leaving them little time to search for additional knowledge and information. The farmer training centers where field agents are based are generally underresourced.

Aside from salaries and organizational funding, a study in Nepal shows that local knowledge and motivation of extension staff at various levels, and not the traditional indicators of organizational capacity (for example, resources, professionalism, and autonomy), are more effective in effecting access to extension services (Kyle and Resnick 2019). Monitoring and evaluation systems for extension were also weak. In the Latin American case, there was a widespread lack of baseline information, monitoring and evaluation, and feedback systems on the delivery and performance of extension systems. Cofinancing schemes were introduced in many countries (Chile, Colombia, Nicaragua, and Peru) to increase small farmer ownership of outputs and to enable greater coverage (Preissing et al. 2018). The lack of extension 
FIGURE 3.1 Net annual salary of agricultural extension service professionals in the public sector in South America (US\$)

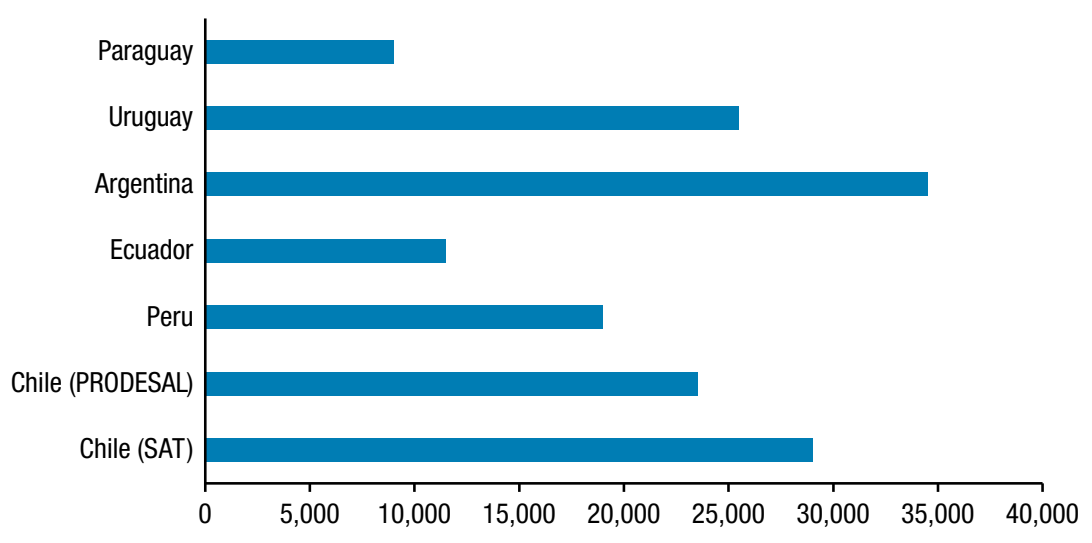

Source: Preissing et al. (2018).

Note: PRODESAL = Programa de Desarollo Local (Local Development Program); SAT = Servicios Agricolas Technicos (Technical Advisory Services).

performance indicators is a critical vacuum in Latin American extension systems. In Malawi farmer-to-agent and farmer-to-lead farmer ratios are persistently used as its main extension performance indicators at the national level. Monitoring should also go beyond measuring just access to extension services, to the level of adoption of improved technologies and practices as well as changes in productivity and incomes. There is potential for information technology and data analytics to collect data and provide relevant and frequent updates to different stakeholders at various levels (see Chapter 6 on Ethiopia) on climate and soil conditions; status of extension services, input use, and technology adoption; and how all these drive development outcome indicators.

\subsection{Advisory Methods}

Advisory methods include the different means to serve clients and provide information, empower farmers, and otherwise fulfill the extension mandate in each country. Many countries are moving from top-down to more participatory methods and to market-oriented approaches rather than a sole focus on production. There is also a trend to use more modern information and communications technologies in extension, as well as the tried-and-tested technologies such as radio. A number of approaches intended to enhance inclusion of 
disadvantaged groups (such as women, youth, and pastoralists) also exist. One point that is clear is that all countries use a wide variety of methods (for example, Figure 3.2). The sections below discuss traditional, participatory, information and communication technology-based methods, and farmer-focused and inclusive approaches.

Traditional methods such as workshops, field days, meetings, and media (for example, brochures, newsletters, and websites) were used by public and private extension systems of Central Asia and the Caucasus (Dosov 2018). Armenian extension mainly used trainings (workshops, field days), consultancies (meetings, discussions), research, introduction of new technologies and best practices, and media such as brochures, newsletters, and websites. Extension methods in Kyrgyzstan included training, lectures, presentations, demonstrations, field visit days, mass media, movies, articles, group activities, practical work, experience exchange, seminars, and round tables (Dosov 2018). In the Democratic Republic of the Congo the main approach to extension was still heavily based on the training-and-visit system, remnants of the World Bank-supported program of the 1980s (see Chapter 8). In Ethiopia several extension methods were often used in combination, including door-to-door extension, farm-to-farm extension, development group meetings, community meetings, field demonstrations, and training at farmer training centers (see Chapter 6).

The breadth and depth of participatory extension methodologies have been increasing (rural promoters, learning groups, local innovation networks, etc.). These provide small producers with greater opportunities for coexecution of extension and inclusion of greater local knowledge. In Argentina, Chile, Colombia, and Uruguay, more participatory strategies and capacity development also are being used (Preissing et al. 2018). In the case of Peru and Ecuador, participatory approaches such as farmer-to-farmer, farmer field schools, and learning-by-doing were used. Participatory methodologies dominated in Brazil (see Chapter 4), where extension workers employed facilitation approaches in connecting farmers to government programs and the financial sector through their endorsement of the farmers for creditworthiness.

In Central America, 55 percent assigned a medium priority and 26 percent a high priority in the use of information and communications technologies in extension strategies (Preissing et al. 2018). In the private sector, 75 percent stated that these technologies should have a greater priority in the future. In Central America, 84 percent of the extensionists noted that beneficiaries had access to the technicians through cell phones. However, only 42 percent stated that their beneficiaries had access to email. 
FIGURE 3.2 Agriculture extension service methodologies used in Argentina, Chile, and Colombia (\%)

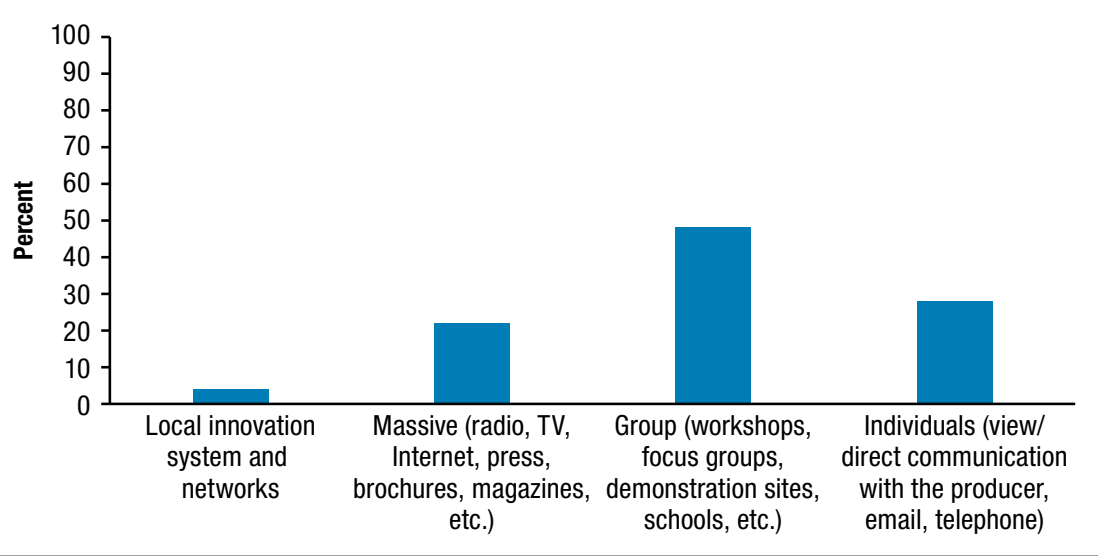

Source: Preissing et al. (2018).

\section{ICT and Digital Technologies}

There also is growing recognition of the value of information and communication technologies. The use of cell phones is almost universal even in rural communities. However, there was still very little use of digital technologies by extension workers in many of the countries, beyond pilot projects (Franzel, Ndiaye, and Tata 2018; Preissing et al. 2018). Radio has been and continues to be an important technology to reach farmers with information (Rao 2015; Ragasa et al. 2019; see Chapter 7 on Malawi and Chapter 8 on the Democratic Republic of the Congo). However, extension programs are now using television (Kiptot et al. 2016), video (Bentley, Chowdhury, and David 2015), apps (Payne and Makh 2018), and mobile and smartphones (van Campenhout, Spielman, and Lecoutere 2018) to share information. Programs such as WhatsApp and Facebook Live are used by service providers to reach their clientele.

The use of ICT applications for extension has expanded greatly in India due to the high penetration of mobile phones in rural areas (Babu and Shishodia 2018). Provision of technological solutions, especially from private-sector providers through mobile phones, has been increasing rapidly. Initiatives are transforming traditional agricultural systems by using such methods as community radio, short message services, voice-based messaging, and Internet kiosks. Yet the context specificity of the messages is lacking as the farming systems are becoming highly heterogenous and more and more 
farmers are going in for diversified farm enterprises and moving away from traditional farming practices. Farmer associations tend to use participatory methods for sharing latest information on specific commodity value chains.

There has been a large increase in the number of telephone users and Internet subscribers since 2008 in Cambodia as well (Ke and Babu 2018). However, lack of capacity and shortage of staff at the national and local levels constrain information sharing among extension workers and farmers. The Department of Extension promoted information and communications technologies for message delivery as well as digitally-enabled rural information centers and community-based farmer radio and television programs. However, there is a need to increase the relevance of the content shared through mobile applications. The typical methods used in Viet Nam include technical training, extension model building, study tours, communication, and providing farmers with updated knowledge and new farming techniques (Ngan and Babu 2018). Farmer associations have played a critical role in sharing knowledge among their members as well.

Another trend in terms of advisory approaches is the use of volunteer farmers, also known as lead farmers, farmer-trainers, volunteer farmers, village agents, or community advisers. This can be seen as a form of private-sector extension where there is sometimes commercialization of the services provided by local farmers and other rural actors. Many lead farmers are selected by communities to work closely with government, private, or nongovernmental extension. Lead farmers are, of course, locally-based and speak local languages; they thus have the trust of fellow villagers. A survey of 80 organizations using lead farmers in Cameroon, Kenya, and Malawi found that the approach was used in part due to its low cost, expansion of reach, and improved accountability to the community (Franzel et al. 2015). Lead farmers may or may not receive salary or incentives in the form of operating cost payments or subsidized or free inputs for demonstrations. Studies have shown that nonmonetary factors such as recognition and altruism play a role in motivating lead farmers (Franzel, Sinja, and Simpson 2014). Such local extension support people need coaching and technical backstopping to be effective, and they need community recognition and support; without these they may perform poorly (Franzel et al. 2015; Behaghel et al. 2018; Ragasa 2019).

A similar model is the "village agent model" started by Sasakawa Global 2000 and promoted by the United States Agency for International Development (USAID) in Uganda. Similar models are used in Tanzania (DLEC 2019) and Rwanda (the latter with the so-called farmer promoters) (MacNairn 2018). Village agents may be linked up to transport companies, 
agro-input companies, or offtakers, and may provide such services as advice, spraying, or bulking. They may receive a fee for their services or a commission from sales. Particularly in Africa, there has been a focus on reaching and engaging youth in extension and advisory services (defining "youth" broadly, normally someone between 15 and 35 years of age). This is a big switch from the 1989 study. The Food and Agriculture Organization of the United Nations (FAO) reported in 1993 that rural youth was one of the program areas of least importance. Percentage of time and resources spent to reach young farmers or rural youth varied between 2 percent and 16 percent (FAO 1993). In 2012 this varied between 4 percent and 14 percent (GFRAS 2012). Ghana has been experimenting on training and deploying youth extension agents. Latest estimates (April 2019) supplied by Ghana's Ministry of Food and Agriculture (MoFA) suggests there are around 1,700 agricultural extension agents, 950 district (agricultural) development officers, and 5,100 youth extension agents deployed under the Nation Builders Corps (NABCO) and Youth Employment Agency (YEA) programs to address (graduate) youth unemployment. ${ }^{3}$ A planned assessment of this approach is under way.

Today there are special programs and projects to engage youth in extension and advisory services. In Guinea a donor-funded program emphasizes human capacity development of youth entrepreneurs and equips them to become private-sector agents after training (DLEC 2019; MacNairn 2017). In Niger youth advisory services organizations provide services mostly to youth (more than 50 percent of the clientele). These services appear free of charge but are actually remunerated through the provision of other services including sales inputs (seeds, fertilizers, etc.) (Djamen 2019). In Guatemala, Rural Development Learning Centers are training centers comprised of organized community members coordinated by rural agricultural promoters. The rural agricultural promoter is a community member who has demonstrated leadership in guiding rural development and serves as a liaison between the community and the extension agents (Chaisson-Cardenas 2019).

\subsection{Cross-Cutting Issues}

The country and regional case studies reported in this chapter brought out several cross-cutting issues such as gender and youth (and generally social inclusion), nutrition, and climate change. Inclusiveness in extension systems

3 For more information, see NABCO (https://nabco.gov.gh/about/) and YEA (https://www.yea .gov.gh/). 
is often seen as a criterion for social impact of extension since the majority of extension services is captured by the large progressive farmers who are on the lookout for new information. Given the limited resources for extension, extension agents in Latin America more often reach out to farmers along the major highways and places easily accessible. Farmers in remote areas are often left out in the process. Furthermore, women farmers are left out as most of the extension workers tend to be men and, due to cultural issues, women are often not connected to innovation systems. The farmers of the lower social castes, black farmers and farmers, in Native communities in Latin America, are more likely to be left out by the standard extension system.

In Latin America programs emphasized social inclusion, rural innovation, markets, and rural territorial development, and moved extension from vertical technical and productivity issues to broader roles. Guatemala had several programs and strategies targeting youth and indigenous communities (Chaisson-Cardenas 2019). There were many successful programs that targeted women farmers (for example, the Ecuadorian Tungurahua Agricultural Strategy, which serves 70 percent of women, and the Zero Hunger program in Nicaragua, which targets women farmers and produced valuable lessons). The territorial development approach used in the region provided an opportunity for extension to be more receptive to local needs and to work with diversified approaches based on agroecological and socioeconomic conditions, ensuring that the service offered is made to measure (Preissing et al. 2018). The Brazilian extension policy attempted to be very inclusive and had action lines on gender, ethnic groups, and youth (see Chapter 4). However, farmers in several of the surveyed territories saw this indicator in the study as having the lowest performance among the different indicators of extension.

In the Democratic Republic of the Congo, the case study showed little participation of women in extension ( 5 percent to 9 percent), especially in leadership positions (see Chapter 8). Leading constraints to women's participation were social norms and mobility. However, female extension workers serve a higher proportion of female farmers than do male agents. Also related to gender of the extension staff is the issue of age, whereby a sizable portion of Congolese agents, especially from government, were near the retirement age (this was also the case in many African countries such as Guinea) (MacNairn 2017).

In India, district-level decentralized farm science centers known as Krishi Vigyan Kendras were shown to be effective at increasing income and self-confidence among women through gender-sensitive programs (Babu and 
Shishodia 2018). However, there is considerable room for improvement in giving greater emphasis on adaptation to climate change to increase yields sustainably. Nutrition as a subject matter is not part of the extension system in India. Although nutrition was taught as part of the undergraduate curriculum two decades ago, slowly it was removed as separate colleges of home sciences were created as part of the agricultural universities. Yet the graduates of the home science colleges are not employed as extension professionals. There is room for collaboration at the community level between village nutrition assistants of the integrated nutrition programs and agricultural extension workers. This coordination will have to take a back seat, until the coordination among the institutions of the agricultural innovation system is improved.

In Cambodia women had low access to land, extension, financial services, markets, and technology (Ke and Babu 2018). Recently, climate change has become a main issue in Cambodia due to increasing droughts, floods, and changes in monsoon seasons. In Viet Nam women generally had low access to extension, production inputs, and capital compared to that of men (Ngan and Babu 2018). Young agricultural extension staff account for a large proportion of the total in Viet Nam. Since 2016, the National Center for Extension has organized many training courses to encourage young farmers to come into agriculture.

Special topics such as climate change or nutrition are generally only covered in projects rather than in mainstreamed extension services (for example, in Guinea [MacNairn 2017] and Liberia [Sigman 2017]). In Liberia the Ministry of Agriculture had a capacity development plan for Climate Change Management in Agriculture developed through a climate change adaptation project that trained public extension staff (Sigman 2017). Climate change adaptation is a subtopic (with limited allocated funding) of the Comprehensive Africa Agriculture Development Programme (CAADP) and the National Agricultural Investment Plan (NAIP) in the Democratic Republic of the Congo. Extension agents were not generally trained on the topic of nutrition (see Chapter 8).

Climate change is projected to have a negative impact on the Central Asia and Caucasus region, where countries are at different stages in terms of defining and implementing their climate change strategies. Currently, there is no regional intergovernmental body with an explicit mandate to support regional cooperation on climate change across a broad range of sectors (Dosov 2018). Although nutrition is a topic in many high-level meetings and documents, it was not seriously addressed by extension staff and their programs. 


\subsection{Conclusion}

There are a wide number of studies looking at the status of extension and advisory services mainly since 2015 . Although these studies had different purposes and methodologies, there is still useful information with regard to the best-fit characteristics of extension: governance structures, capacity, management, and advisory methods used. Cross-cutting issues such as gender, youth, nutrition, and climate change were also examined. The majority of countries have pluralistic extension systems with a large number of public, private, and civil society providers (see Table 3.1). The public sector, usually the ministries of agriculture, is responsible for the overall coordination and regulation of extension. Many countries are starting to decentralize the services to lower levels of governance.

A number of countries do not have a specific policy for extension and advisory services; these are usually rooted in broader agricultural sector development policies. Some countries have a policy that is outdated or not well implemented. There are a few examples of countries with updated, well-financed, and well-implemented extension policies. Coordination between players and with other actors in the agricultural innovation system remains a challenge in most countries, although we see some mechanisms to deal with this in Malawi and Brazil. Financing of extension services is quite diverse in Latin America; in Africa and Central Asia and the Caucasus, it is very donor-dependent and public sector-led (while Rwanda and Ethiopia do use donor funds, their extension programs are driven by their extension and agriculture strategies rather than by donor priorities).

Numbers of extension agents from the public sector are seldom sufficient for the job at hand, and there are high vacancy rates and turnover in some countries. The foundational training for extension agents is usually focused on technical topics and may miss out on functional skills that are also needed for extension. One exception is several Central and South American countries that appear to have well-established foundational and continuing education systems for extension providers. A few countries provide incentives for extension agents. In most cases extension agents are demotivated and lack basic transportation and equipment. Salaries are normally low, especially in the public sector, and there are few rewards or recognition. Lead farmers and rural promoters are often used, but they also struggle with community recognition and support as well as support from the public extension system.

Methods used for advising are quite diverse. Most of the countries tend to use traditional methods such as individual and group communication approaches; however, there is a trend toward more participatory approaches, 
such as farmer field schools, and toward the use of more ICTs beyond radio and television. Most countries use some type of multiplier approach such as farmer extensionists or rural promoters. A number of methods exist to strengthen social inclusion. While there is increasing emphasis on reaching women, youth, or other disadvantaged populations, this is largely in certain projects and not necessarily mainstreamed, nor is much known on the effectiveness of such approaches. Focus on climate change and climate-smart approaches are rapidly growing and being taken up in many programs and promoted with a number of methods. Incorporation of nutrition issues in the extension content is only in the discussion stage in several countries.

\subsection{Policy Recommendations}

Part 1 of this book has given indications of the difficulties but also the necessity of collecting indicators on extension and advisory services. Although this book uses the best-fit framework to guide analysis of extension services, the framework falls short in establishing a common set of indicators against which to measure outcomes and impacts. Since the 2012 GFRAS survey of extension systems in the developing countries, there have been several initiatives to continue to collect global (and internationally comparable) data and to establish common indicators for extension. The World Bank, USAID, IFPRI, and FAO have been discussing the issue since the early 2000s. Around 2016, the Bill and Melinda Gates Foundation initiated work on a number of "dashboards," sets of indicators that could be compared across countries. On the extension topic, this was done with regard to budget distribution, numbers of extension workers, relevance of content, reach, adoption rate, and other, more system-level characteristics. The extension dashboard was initially trialed in three places: Tanzania, Ethiopia, and Bihar in India. This work is still in development and has struggled with stakeholder buy-in (DLEC 2018).

At the same time, the Global Forum for Rural Advisory Services, together with its regional networks and national platforms, proposed the establishment of "extension observatories" as part of a new funding proposal (IFAD 2018). The observatories are meant to continuously collect and make information on extension indicators accessible through national platforms, which will contribute to the information base of the African Observatory of Science, Technology and Innovation that is being developed by the African Union to champion evidence-based science, technology, and innovation policy-making by backstopping African countries to manage and use statistical information 
(AOSTI 2013). These observatories seemingly echo the Agricultural Science and Technology Indicators (ASTI) initiative, which provides open-source data on agricultural research systems across the developing world. ASTI, however, has likely gained more traction because research data are easier to obtain than extension data due in part to the existence of agreed-upon definitions and conventions on what constitutes research and how to measure it-the Frascati Manual, which is based on work dating back to 1963 (OECD 2015). This further reinforces the need for agreed-upon definitions and conventions for extension and advisory services (DLEC 2018).

The organizations mentioned above that are grappling with the issue of collecting extension data see value in having an established set of metrics to consistently assess the performance of extension systems across many contexts. This can help to share and adapt learning across multiple settings and guide policymakers, funders, and extension implementers regarding what innovations and activities to invest in to maximize impact (DLEC 2018). The earlier efforts (FAO 1991; GFRAS 2012) to collect extension metrics focused on what might be described as the "input" side of the equation. These indicators included, for example, the number of extension agents in service, public expenditures allocated to extension, farmer-to-extension agent ratios, and number and type of extension providers across the public, private, and civil society sectors. Input metrics are useful in determining where to allocate scarce public resources within the broad area of agriculture and rural development but tend to reveal only part of the story and are not as useful in determining how to use these resources within existing or planned programs. First, and by definition, they are generally unable to capture the short- or long-term outcomes associated with extension: improvements in productivity, sustainability, income, or social equity. Second, they do not reflect system-level performance, such as the performance of structures, processes, and relationships between and among extension providers and other actors in the agricultural sector. Thus higher order metrics are needed to supplement the input metrics and help extension stakeholders design for and measure across a range of outcomes (DLEC 2018).

Any common set of extension metrics will still run into the challenge that data are hard to come by given that, among other reasons, many countries do not explicitly budget extension services as a separate or distinct line item so the lines of what defines extension is often blurry and different across contexts (DLEC 2018). In addition, the combination of pluralistic actors providing extension, multiple channels being used for information sharing, and the decentralization of advisory services in many countries provide challenges in 
identifying from whom to collect extension metrics, and how to identify their financial, technical, and human resource investments in extension in a comparable manner. Where extension and advisory services are associated with proprietary information and supply-chain contracts or commercial technologies, data are often even more difficult to obtain.

As governments and development partners recognize the importance of farmer-based learning processes, last-mile delivery, and other elements that are critical to advancing rural advisory services, there is a recognized need to invest more strategically in extension. This requires good data and analysis to adequately understand the most effective extension strategies. The data need to serve the learning needs of researchers, policymakers, funders, and extension providers on how to design and implement an advisory service system that draws from global successes while taking into consideration contextual specificities. However, country- and project-specific metrics and data as they are currently designed do not necessarily enable a global conversation on what national extension systems are getting right and what other countries can learn from them (DLEC 2018).

In 2018 a set of organizations again took up the challenge of "common extension metrics" to propose a common set of indicators that not only focus on the "input" side of extension, but system, delivery, outputs, outcomes, and even impact domains (DLEC 2018). Spearheaded by the Developing Local Extension Capacity (DLEC) project, they formed a task force consisting of members from the World Bank, USAID, and IFPRI, and started work on common definitions and indicators for extension. The task force started from the Bill and Melinda Gates Foundation initial dashboard but also used a literature review to identify other sources of extension metrics across the various domains. ${ }^{4}$ While still a work in progress, indicators that were identified as promising by the task force are shared in Table 3.2.

The table relates the indicators to the dimensions from the best-fit framework (see Figure 1.2 in Chapter 1). There are several caveats. Many of these indicators are aspirational and do not currently exist. Indicator numbers 1-19 are descriptive data; indicators $20-25$ should be evaluated rigorously as to how extension services contribute to these outcome indicators. Despite being a work-in-progress, based on the continued (text continues on page 91)

4 For Ethiopia specifically the Gates Foundation developed 10 indicators: (1) share of public budget on extension; (2) extension budget per household; (3) financial incentive of an extension agent; (4) continuous improvement processes; (5) households reached by public extension; (6) households reached by all extension; (7) ICT as a main source of extension; (8) quality of public extension; (9) services to female farmers; and (10) inclusivity. 
TABLE 3.2 Potential indicators, data sources, availability by best-fit dimension

\begin{tabular}{|c|c|c|c|c|}
\hline $\begin{array}{l}\text { Indicator } \\
\text { number }\end{array}$ & $\begin{array}{l}\text { Best-fit } \\
\text { dimension }\end{array}$ & Indicator name & Data source (year) & Availability \\
\hline 1 & $\begin{array}{l}\text { Governance- } \\
\text { financing }\end{array}$ & $\begin{array}{l}\text { Share of public budget } \\
\text { on extension. Total } \\
\text { government (public) } \\
\text { extension budget divid- } \\
\text { ed by total agriculture } \\
\text { budget }(\%)\end{array}$ & $\begin{array}{l}\text { Monitoring and Analyz- } \\
\text { ing Food and Agricul- } \\
\text { tural Policies; country } \\
\text { governments; national } \\
\text { statistics offices }\end{array}$ & Available data \\
\hline 2 & $\begin{array}{l}\text { Governance- } \\
\text { financing }\end{array}$ & $\begin{array}{l}\text { Government budget } \\
\text { per household. Total } \\
\text { government (public) } \\
\text { extension budget } \\
\text { per } 1,000 \text { rural farm } \\
\text { households (purchasing } \\
\text { power parity dollar per } \\
\text { farming household per } \\
\text { year) }\end{array}$ & $\begin{array}{l}\text { Monitoring and Analyz- } \\
\text { ing Food and Agricul- } \\
\text { tural Policies; country } \\
\text { governments; national } \\
\text { statistics offices; World } \\
\text { Bank, World Develop- } \\
\text { ment Indicators }\end{array}$ & Available data \\
\hline 3 & $\begin{array}{l}\text { Governance- } \\
\text { financing }\end{array}$ & $\begin{array}{l}\text { Cost of extension. Total } \\
\text { government (public) } \\
\text { extension expenditure } \\
\text { divided by per unit value } \\
\text { of production }\end{array}$ & $\begin{array}{l}\text { Country governments; } \\
\text { FAOSTAT }\end{array}$ & Aspirational \\
\hline 4 & $\begin{array}{l}\text { Frame condi- } \\
\text { tions }\end{array}$ & $\begin{array}{l}\text { Systems index. Country } \\
\text { score on extension pol- } \\
\text { icy, linkages, pluralism, } \\
\text { and digital management }\end{array}$ & Country governments & Aspirational \\
\hline 5 & Performance & $\begin{array}{l}\text { Relevance/farmer } \\
\text { demand index. Country } \\
\text { score on whether } \\
\text { extension system } \\
\text { incorporates farmer } \\
\text { voice and is relevant to } \\
\text { their needs }\end{array}$ & Country governments & Aspirational \\
\hline 6 & Capacity & $\begin{array}{l}\text { Farming house- } \\
\text { holds reached by all } \\
\text { extension. Share of } \\
\text { households receiving } \\
\text { extension services (pub- } \\
\text { lic or otherwise) (\%) }\end{array}$ & $\begin{array}{l}\text { Living Standards in } \\
\text { Measurement Study_- } \\
\text { Integrated Surveys on } \\
\text { Agriculture for some } \\
\text { countries }\end{array}$ & Available data \\
\hline 7 & Capacity & $\begin{array}{l}\text { Farming households } \\
\text { directly reached by } \\
\text { public extension. Share } \\
\text { of households receiving } \\
\text { advice from a public } \\
\text { extension agent (\%) }\end{array}$ & $\begin{array}{l}\text { Living Standards in } \\
\text { Measurement Study- } \\
\text { Integrated Surveys on } \\
\text { Agriculture for some } \\
\text { countries }\end{array}$ & Available data \\
\hline
\end{tabular}




\begin{tabular}{|c|c|c|c|c|}
\hline $\begin{array}{l}\text { Indicator } \\
\text { number }\end{array}$ & $\begin{array}{l}\text { Best-fit } \\
\text { dimension }\end{array}$ & Indicator name & Data source (year) & Availability \\
\hline 8 & $\begin{array}{l}\text { Advisory } \\
\text { methods }\end{array}$ & $\begin{array}{l}\text { Households reached } \\
\text { by information and } \\
\text { communications } \\
\text { technologies. Share of } \\
\text { households identifying } \\
\text { information and com- } \\
\text { munications technolo- } \\
\text { gies as main source of } \\
\text { extension (\%) }\end{array}$ & $\begin{array}{l}\text { Living Standards in } \\
\text { Measurement Study- } \\
\text { Integrated Surveys on } \\
\text { Agriculture for some } \\
\text { countries }\end{array}$ & Available data \\
\hline 9 & Capacity & $\begin{array}{l}\text { Farming households } \\
\text { per public extension } \\
\text { agents. Number of } \\
\text { farming households per } \\
\text { public extension agent }\end{array}$ & $\begin{array}{l}\text { World Bank, World } \\
\text { Development Indicators; } \\
\text { GFRAS Worldwide ex- } \\
\text { tension survey (GFRAS } \\
\text { 2012) }\end{array}$ & Available data \\
\hline 10 & Capacity & $\begin{array}{l}\text { Age of public extension } \\
\text { agents. Average age of } \\
\text { public extension agents }\end{array}$ & Country governments & Aspirational \\
\hline 11 & Management & $\begin{array}{l}\text { Financial incentive of } \\
\text { an extension agent. } \\
\text { Ratio of an extension } \\
\text { agent's daily wage rate } \\
\text { to a rural teacher's daily } \\
\text { wage rate }\end{array}$ & Country governments & Aspirational \\
\hline 12 & Capacity & $\begin{array}{l}\text { Continuous im- } \\
\text { provement process. } \\
\text { Proportion of extension } \\
\text { personnel annually } \\
\text { trained in specialized } \\
\text { courses }\end{array}$ & Country governments & Aspirational \\
\hline 13 & Performance & $\begin{array}{l}\text { Service to female } \\
\text { farmers. Share of } \\
\text { females in smallholder } \\
\text { farming households } \\
\text { reporting receiving } \\
\text { extension services (\%) }\end{array}$ & $\begin{array}{l}\text { Living Standards in } \\
\text { Measurement Study- } \\
\text { Integrated Surveys on } \\
\text { Agriculture for some } \\
\text { countries }\end{array}$ & Available data \\
\hline 14 & Performance & $\begin{array}{l}\text { Frequency of visits. } \\
\text { Number of times public } \\
\text { extension agents visit } \\
\text { the plot in the past } 12 \\
\text { months }\end{array}$ & $\begin{array}{l}\text { Living Standards in } \\
\text { Measurement Study- } \\
\text { Integrated Surveys on } \\
\text { Agriculture }\end{array}$ & Available data \\
\hline 15 & Performance & $\begin{array}{l}\text { Inclusivity. Index (0-1) } \\
\text { of inclusivity of exten- } \\
\text { sion services relative } \\
\text { to a defined disenfran- } \\
\text { chised group }\end{array}$ & $\begin{array}{l}\text { Country governments } \\
\text { for some countries }\end{array}$ & Aspirational \\
\hline
\end{tabular}


TABLE 3.2 Continued

\begin{tabular}{|c|c|c|c|c|}
\hline $\begin{array}{l}\text { Indicator } \\
\text { number }\end{array}$ & $\begin{array}{l}\text { Best-fit } \\
\text { dimension }\end{array}$ & Indicator name & Data source (year) & Availability \\
\hline 16 & Performance & $\begin{array}{l}\text { Farming households } \\
\text { that receive marketing } \\
\text { information. Share of } \\
\text { households receiving } \\
\text { advice from public } \\
\text { extension on marketing } \\
\text { (\%) }\end{array}$ & $\begin{array}{l}\text { Living Standards in } \\
\text { Measurement Study- } \\
\text { Integrated Surveys on } \\
\text { Agriculture for some } \\
\text { countries }\end{array}$ & Available data \\
\hline 17 & Performance & $\begin{array}{l}\text { Farming households } \\
\text { that receive livestock } \\
\text { information. Share of } \\
\text { households with live- } \\
\text { stock receiving advice } \\
\text { from public extension } \\
\text { on livestock (\%) }\end{array}$ & $\begin{array}{l}\text { Living Standards in } \\
\text { Measurement Study- } \\
\text { Integrated Surveys on } \\
\text { Agriculture for some } \\
\text { countries }\end{array}$ & Available data \\
\hline 18 & Performance & $\begin{array}{l}\text { Quality of public exten- } \\
\text { sion. Share of house- } \\
\text { holds reporting public } \\
\text { extension services as } \\
\text { at least "somewhat } \\
\text { useful" (\%) }\end{array}$ & $\begin{array}{l}\text { Living Standards in } \\
\text { Measurement Study- } \\
\text { Integrated Surveys on } \\
\text { Agriculture for some } \\
\text { countries }\end{array}$ & Available data \\
\hline 19 & $\begin{array}{l}\text { Farm house- } \\
\text { holds }\end{array}$ & $\begin{array}{l}\text { Adopters of practices } \\
\text { and technologies. } \\
\text { Share of total number } \\
\text { of adopters divided by } \\
\text { number of households } \\
\text { receiving extension } \\
\text { advice from public } \\
\text { services }\end{array}$ & Country governments & Aspirational \\
\hline 20 & $\begin{array}{l}\text { Farm house- } \\
\text { holds }\end{array}$ & $\begin{array}{l}\text { Adoptions of practices } \\
\text { and technologies. } \\
\text { Share of total number } \\
\text { of adoptions divided } \\
\text { by total number of } \\
\text { adopters }\end{array}$ & Country governments & $\begin{array}{l}\text { Available house- } \\
\text { hold survey panel } \\
\text { (secondary or } \\
\text { primary), analyzed } \\
\text { using rigorous } \\
\text { impact evaluation } \\
\text { methods }\end{array}$ \\
\hline 21 & Impact & $\begin{array}{l}\text { Women's empow- } \\
\text { erment. Women's } \\
\text { Empowerment in } \\
\text { Agriculture Index }\end{array}$ & $\begin{array}{l}\text { Women's Empowerment } \\
\text { in Agriculture Index } \\
\text { (IFPRI 2012) }\end{array}$ & $\begin{array}{l}\text { Available house- } \\
\text { hold survey panel } \\
\text { (secondary or } \\
\text { primary), analyzed } \\
\text { using rigorous } \\
\text { impact evaluation } \\
\text { methods }\end{array}$ \\
\hline 22 & Impact & $\begin{array}{l}\text { Yield. Average agri- } \\
\text { cultural production per } \\
\text { hectare of land }\end{array}$ & $\begin{array}{l}\text { Living Standards in } \\
\text { Measurement Study- } \\
\text { Integrated Surveys on } \\
\text { Agriculture for some } \\
\text { countries }\end{array}$ & $\begin{array}{l}\text { Available house- } \\
\text { hold survey panel } \\
\text { (secondary or } \\
\text { primary), analyzed } \\
\text { using rigorous } \\
\text { impact evaluation } \\
\text { methods }\end{array}$ \\
\hline
\end{tabular}




\begin{tabular}{|c|c|c|c|c|}
\hline $\begin{array}{l}\text { Indicator } \\
\text { number }\end{array}$ & $\begin{array}{l}\text { Best-fit } \\
\text { dimension }\end{array}$ & Indicator name & Data source (year) & Availability \\
\hline 23 & Impact & $\begin{array}{l}\text { Income (net profit). } \\
\text { Average income (that is, } \\
\text { net profit) from farming } \\
\text { activities per hectare } \\
\text { of land }\end{array}$ & $\begin{array}{l}\text { Living Standards in } \\
\text { Measurement Study_- } \\
\text { Integrated Surveys on } \\
\text { Agriculture for some } \\
\text { countries }\end{array}$ & $\begin{array}{l}\text { Available house- } \\
\text { hold survey panel } \\
\text { (secondary or } \\
\text { primary), analyzed } \\
\text { using rigorous } \\
\text { impact evaluation } \\
\text { methods }\end{array}$ \\
\hline 24 & Impact & $\begin{array}{l}\text { Poverty. Percentage } \\
\text { of the rural population } \\
\text { living below the national } \\
\text { poverty lines }\end{array}$ & $\begin{array}{l}\text { World Bank, Global } \\
\text { Poverty Working Group }\end{array}$ & $\begin{array}{l}\text { Available house- } \\
\text { hold survey panel } \\
\text { (secondary or } \\
\text { primary), analyzed } \\
\text { using rigorous } \\
\text { impact evaluation } \\
\text { methods }\end{array}$ \\
\hline 25 & Impact & $\begin{array}{l}\text { Environmental sustain- } \\
\text { ability. Emissions from } \\
\text { agriculture }\end{array}$ & $\begin{array}{l}\text { FAOSTAT, http://www } \\
\text {.fao.org/faostat }\end{array}$ & $\begin{array}{l}\text { Available house- } \\
\text { hold survey panel } \\
\text { (secondary or } \\
\text { primary), analyzed } \\
\text { using rigorous } \\
\text { impact evaluation } \\
\text { methods }\end{array}$ \\
\hline
\end{tabular}

Source: Authors' compilation, adapted from ALINE (2019).

importance of extension and advisory services, it will be valuable for stakeholders - funders, implementers, and evaluators of the services - to continue thinking about the best measures for extension.

\section{References}

ALINE (Agricultural Learning and Impacts Network). 2019. "Improving Agricultural Advisory Systems Metrics and Learning." Meeting summary, April 8-9, 2019, Addis Ababa, Ethiopia. AOSTI (African Observatory of Science, Technology, and Innovation). 2013. Science, Technology and Innovation Policy-Making in Africa: An Assessment of Capacity Needs and Priorities. AOSTI Working Papers 2. Malabo, Equatorial Guinea: AOSTI.

Babu, S. C., and M. Shishodia. 2018. “India.” Unpublished report. International Food Policy Research Institute (IFPRI), Washington, DC.

Behaghel, L., J. Gignoux, M. K. Beraho, J. Kugonza, K. Macours, M. N. Mangheni, and J. Oduol. 2018. Dissemination of New Agricultural Technologies in Africa: Making Extension Work: Impact Evaluation of a Farmer Trainer Program in Uganda. Final project report. New Delhi; Cambridge, MA, US; Paris: 3ie/J-PAL/Paris School of Economics. 
Bentley, J., A. Chowdhury, and S. David. 2015. Videos for Agricultural Extension. Note 6. GFRAS Good Practice Notes for Extension and Advisory Services. Lindau, Switzerland: Global Forum for Rural Advisory Services (GFRAS).

Burrows, E., M. Bell, and N. G. Rutamu. 2017. Extension and Advisory Services in Zambia: Understanding Structures, Services, Roles and Incentives for Reaching Farmer Households As a Basis for Discussing Potential for Scale. Integrating Gender and Nutrition within Agricultural Extension Services (INGENAES). Urbana-Champaign, IL, US: University of Illinois.

Cai, T. 2017. Malawi: Desk Study of Extension and Advisory Services. Washington, DC: Developing Local Extension Capacity (DLEC) Project.

Chaisson-Cardenas, J. P. 2019. Youth in Extension and Advisory Services: Guatemala. Washington, DC: DLEC Project.

Cuangara, B., and T. Thompson. 2018. Mozambique: Desk Study of Extension and Advisory Services. Washington, DC: DLEC Project.

Djamen, P. N. 2019. "Youth in Agricultural Extension in Niger." Unpublished report. Washington, DC, DLEC Project.

DLEC (Developing Local Extension Capacity Project). 2018. Mali: In-Depth Assessment of Extension and Advisory Services. Washington, DC: DLEC Project.

- 2019. Strengthening Private Sector Extension and Advisory Services-Portfolio Review. Washington, DC: DLEC Project.

Dosov, B. 2018. "Central Asia and the Caucasus." Unpublished report, Washington, DC, IFPRI.

FAO (Food and Agriculture Organization of the United Nations). 1991. International Directory of Agriculture Extension Organizations. Rome: FAO.

-1993. Agricultural Extension and Farm Women in the 1980s. Rome: FAO.

_ 2010. FAOSTAT database. Accessed October 9, 2018. http://www.fao.org/faostat.

Franzel, S., A. Degrande, E. Kiptot, J. Kirui, J. Kugonza, J. Preissing, and B. Simpson. 2015. Farmer-to-Farmer Extension. Note 7. GFRAS Good Practice Notes for Extension and Advisory Services. GFRAS: Lindau, Switzerland.

Franzel, S., A. Ndiaye, and J. S. Tata. 2018. Senegal: In-Depth Assessment of Extension and Advisory Services. DLEC Project. Washington, DC: USAID.

Franzel, S., J. Sinja, and B. Simpson. 2014. Farmer-to-Farmer Extension in Kenya: The Perspectives of Organizations Using the Approach. ICRAF Working Paper 181. Nairobi: World Agroforestry Centre. DOI: http://dx.doi.org/10.5716/W P14380.PDF.

GFRAS (Global Forum for Rural Advisory Services). 2012. "Master Worldwide Extension Study Database.” Excel File, GFRAS, Lindau, Switzerland. https://www.ifpri.org/publication /worldwide-extension-study. 
Goertz, H. 2016. Haiti Landscape Analysis. Integrating Gender and Nutrition within Agricultural Extension Services (INGENAES). Urbana-Champaign, IL, US: University of Illinois.

Huber, S., and K. Davis. 2017. Bangladesh: Desk Study of Extension and Advisory Services. Washington, DC: DLEC Project.

Huber, S., K. Davis, and K. Lion. 2017. Nigeria: In-Depth Assessment of Extension and Advisory Services. Washington, DC: DLEC Project.

IFAD (International Fund for Agricultural Development). 2018. Delivering Extension Services to the Last-Mile: Improving Smallholders' Access to Innovation and Pluralistic, Demand-Driven Extension Services. Grant Design Document. Rome: IFAD.

IFPRI. 2012. Women's Empowerment in Agriculture Index. Washington, DC: IFPRI.

INGENAES. 2015. Senegal Landscape Analysis. Urbana-Champaign, IL, US: University of Illinois. _. 2016a. Rwanda Landscape Analysis. Urbana-Champaign, IL, US: University of Illinois. _.2016b. Tanzania Landscape Analysis. Urbana-Champaign, IL, US: University of Illinois. _.2016c. Uganda Landscape Analysis. Urbana-Champaign, IL, US: University of Illinois. _.2016d. Mali Landscape Analysis. Urbana-Champaign, IL, US: University of Illinois. _. 2016e. Malawi Landscape Analysis. Urbana-Champaign, IL, US: University of Illinois. _.2016f. Liberia Landscape Analysis. Urbana-Champaign, IL, US: University of Illinois. _.2016g. Kenya Landscape Analysis. Urbana-Champaign, IL, US: University of Illinois. _.2016h. Guatemala Landscape Analysis. Urbana-Champaign, IL, US: University of Illinois. _.2016i. Ghana Landscape Analysis. Urbana-Champaign, IL, US: University of Illinois. _.2016j. Ethiopia Landscape Analysis. Urbana-Champaign, IL, US: University of Illinois. _.2016k. Cambodia Landscape Analysis. Urbana-Champaign, IL, US: University of Illinois. _.20161. Mozambique Landscape Analysis. Urbana-Champaign, IL, US: University of Illinois.

- 2017. Sierra Leone Landscape Analysis. Urbana-Champaign, IL, US: University of Illinois. - 2018. Tajikistan Landscape Analysis. Urbana-Champaign, IL, US: University of Illinois. Ke, S. O., and S. C. Babu. 2018. “Cambodia.” Unpublished report. Washington, DC, IFPRI. Kiptot, E., S. Franzel, C. Nora, and A.-M. Steyn. 2016. Edutainment TV for Disseminating Information about Agriculture. Note 22. GFRAS Good Practice Notes for Extension and Advisory Services. GFRAS: Lausanne, Switzerland.

Kyle, J., and D. Resnick. 2019. "Delivering More with Less: Subnational Service Provision in Low Capacity States.” Studies in Comparative International Development 54 (1): 133-163. 
Ludgate, N., and S. J. Tata. 2015. Burundi Landscape Analysis. INGENAES. Urbana-Champaign, IL, US: University of Illinois.

MacNairn, I. 2017. Guinea: Desk Study of Extension and Advisory Services. Washington, DC: DLEC Project.

- 2018. Rwanda: Desk Study of Extension and Advisory Services. Washington, DC: DLEC Project.

Malawi, MoAIWD (Ministry of Agriculture, Irrigation, and Water Development). 2004. Agricultural Extension Policy Implementation Guide. Lilongwe.

McNamara, P., B. E. Swanson, and B. M. Simpson. 2011. Rebuilding and Strengthening the Pluralistic Extension System in Liberia. Modernizing Extension and Advisory Services (MEAS) Project. Urbana-Champaign, IL, US: University of Illinois.

Mwakiwa, E. 2017. Zimbabwe Agricultural Extension Issues Paper. Harare, Zimbabwe: Ministry of Agriculture, Mechanization and Irrigation Development, and the United Nations Development Program.

Ngan, H. P., and S. C. Babu. 2018. "Viet Nam.” Unpublished report, IFPRI, Washington, DC.

OECD (Organisation for Economic Co-Operation and Development). 2015. Frascati Manual 2015: Guidelines for Collecting and Reporting Data on Research and Experimental Development: The Measurement of Scientific, Technological and Innovation Activities. Paris: OECD. https://doi.org/10.1787/9789264239012-en.

Parkinson, V. 2017. Personal communication via email. November 9.

Payne, J., and S. Makh. 2018. Scaling Up Digital Technologies for Extension and Advisory Services Part 1: Digital Extension Typology (Blog). https://www.agrilinks.org/post/ digital-extension-typology.

Preissing, J., S. Ardila, F. Aguirre, and J. Buitrón. 2018. “Latin America.” Unpublished report, IFPRI, Washington, DC.

Ragasa, C. 2019. Modeling the Effectiveness of the Lead Farmer Approach in Agricultural Extension Service Provision: Nationally Representative Panel Data Analysis in Malawi. IFPRI Discussion Paper 1848. Washington, DC: IFPRI.

Ragasa, C., T. Badibanga, and J. Ulimwengu. 2016. "Effectiveness and Challenges of Participatory Governance: The Case of Agricultural and Rural Management Councils in the Western Democratic Republic of the Congo." Food Security 8: 827-854.

Ragasa, C., I. Lambrecht, and D. Kufoalor. 2018. "Limitations of Contract Farming as a Pro-poor Strategy: The Case of Maize Outgrower Schemes in Upper West Ghana." World Development 102: 30-56. 
Ragasa, C., C. Mthinda, C. Chowa, D. Mzungu, K. Kalagho, and C. Kazembe. 2019. “Assessing and Strengthening Malawi's Pluralistic Agricultural Extension System: Evidence and Lessons from a Three-Year Research Study." Project Note, November 13. IFPRI, Washington, DC.

Rahman, M. W., M. S. Islam, L. Hassan, N. Z. Tanny, L. Parvin, and A. Bohn. 2017. Bangladesh Landscape Analysis. INGENAES. Urbana-Champaign, IL, US: University of Illinois.

Rao, S. 2015. Using Radio in Agricultural Extension. Note 18. GFRAS Good Practice Notes for Extension and Advisory Services. GFRAS: Lindau, Switzerland.

Resnick, D. 2018. The Devolution Revolution: Implications for Agricultural Service Delivery in Ghana. IFPRI Discussion Paper 1714. Washington, DC: IFPRI.

Ruml, A., C. Ragasa, and M. Qaim. 2019. "Heterogeneous Effects of Marketing Contracts and Resource-Providing Contracts on Household Income." Global Food paper series draft, University of Goettingen, Germany.

Sigman, V. 2017. Liberia: Desk Study of Extension and Advisory Services. Washington, DC: DLEC Project.

Simpson, B. E., G. Heinrich, and G. Malindi. 2012. Strengthening Pluralistic Agricultural Extension in Malawi. Modernizing Extension and Advisory Services (MEAS) Project. UrbanaChampaign, IL, US: University of Illinois.

Suvedi, M., and P. McNamara. 2012. Strengthening the Pluralistic Agricultural Extension System in Nepal. Modernizing Extension and Advisory Services (MEAS) Project. Urbana-Champaign, IL, US: University of Illinois.

Swanson, B. E. 2011. Assessment of Bangladesh's Pluralistic Extension System. Modernizing Extension and Advisory Services (MEAS) Project. Urbana-Champaign, IL, US: University of Illinois.

Valenzuela, M. A. B., and D. Saavedra. 2017. In-Depth Assessment of Extension and Advisory Services. Washington, DC: DLEC Project.

Van Campenhout, B., D. J. Spielman, and E. Lecoutere. 2018. Information and Communication Technologies (ICTs) to Provide Agricultural Advice to Smallholder Farmers: Experimental Evidence from Uganda. IFPRI Discussion Paper 1778. Washington, DC: IFPRI. http:// ebrary.ifpri.org/cdm/singleitem/collection/p15738coll2/id/133022.

Williams, R. 2016. Honduras Landscape Analysis. INGENAES. Urbana-Champaign, IL, US: University of Illinois.

Zhou, Y., and S. C. Babu. 2015. Knowledge Driven Development. New York: Elsevier. 
